\title{
Seeking the good (peace) of the republic: The violence against and of difference in defining the public space
}

\author{
Author: \\ Johann-Albrecht Meylahn ${ }^{1}$ \\ Affiliation: \\ ${ }^{1}$ Faculty of Theology, \\ University of Pretoria, \\ South Africa \\ Correspondence to: \\ Johann-Albrecht Meylahn \\ Email: \\ jmeylahn@lantic.net \\ Postal address: \\ PO Box 14885, Lyttelton \\ 0140, South Africa \\ Dates: \\ Received: 02 Mar. 2011 \\ Accepted: 15 Mar. 2011 \\ Published: 07 June 2011 \\ How to cite this article: \\ Meylahn, J.A., 2011, 'Seeking \\ the good (peace) of the \\ republic: the violence against \\ and of difference in defining \\ the public space', Verbum \\ et Ecclesia 32(2), Art. \#505, \\ 10 pages. doi:10.4102/ \\ ve.v32i2.505
}

C 2011. The Authors. Licensee: OpenJournals Publishing. This work is licensed under the Creative Commons Attribution License.
This article will reflect on the role of legitimate and authorised violence in state-making. This violence in the name of the good defines the state (Benjamin's law-making violence) by the exclusion of others (Benjamin 1996). Law-making violence together with the violence that coerces or binds [religare] the public into a common understanding of the good (Benjamin's law-maintaining violence) is at the exclusion of other interpretations of the good (Benjamin 1996). As the law-making and law-maintaining violence of the state is always at the expense of the excluded other, the excluded other will produce a counter violence of difference seeking a legitimate place within the common space of the republic (Benjamin's divine violence). What is the church's role in such a context of violence? Is the church's role to help clarify and clearly define the good that will bind [religare] the citizens into a stronger and more prosperous and peaceful state - onward Christian soldiers marching as to war? Or is there another calling, to be disciples of Christ - with the Cross of Jesus going on before - and enter the space of violence beyond the knowledge of good and evil as peacemakers? These questions will be examined by bringing into dialogue Žižek's (1997) interpretation of Christianity with Derrida's (2002) interpretation of hospitality, specifically in the violent South African context.

\section{Introduction}

The theme of the conference, 'Violence in the democratic South Africa: A challenge to theology and the churches', presupposes that there is (or should be) a connection between violence in the democratic republic and theology and thus also the church. What is the nature of this connection? To use terms such as: church, theology, violence, democracy and even South Africa is already a violence as these concepts cannot possibly be all inclusive and thus some interpretations or understandings of these concepts are always excluded.

South Africa's past and present is characterised by violence. There are various different forms and expressions of violence such as domestic violence, political violence, xenophobia, economic violence and violence against women and children and this list is not exhaustive. At this conference one could try and understand the role of the church in each of these different expressions of violence and seek a theological response. This article will, however, seek a more fundamental interpretation or description of violence, namely the violence against and of difference, as I believe that the church is implicated in this violence. With the use of the concept 'fundamental interpretation of violence' I am not suggesting that this violence is the foundation or root of all the other expressions of violence The article will be focusing on the violence of knowing, proclaiming and implementing $a$ or the good after eating from the tree of knowledge of good and evil, which is traditionally (biblically) understood as the original sin. This knowledge is violent as it leads to judgement, condemnation, exclusion and even death of that which is different or other because the different or other is characterised as evil or wrong and therefore not worthy of life. The article will focus on the violence of the knowledge of good and evil as this is the violence that the church in its long history has been and is implicated in. By making such a statement one is committing a great violence: the violence of generalisation.

Yet, this conference is not only about the church, but also about democracy and the Republic (the democratic South Africa). Thus the title of the conference places the theme, 'violence', into a very specific context namely that of the relationship between church, democracy and nation state the republic of South Africa. To understand and interpret this theme one would need to look at the history of the relationships between church (theology), democracy and the nation state (the republic of South Africa). If one looks at this relationship purely from the short South African history of democracy one may come to the generalised conclusion that it is a good (nonviolent) relationship, as certain sectors of the church, besides being involved in the atrocities of Apartheid, are and were involved in the transition to a truly democratic South Africa. Yet, this would be a very naïve reading of democracy in South Africa. Firstly, it presumes that democracy is a good 
that needs to be achieved, which already excludes all those ideas that differ, namely all other possible models of living together in a republic, for example the philosophy of $u b u n t u$ [humanity or kindness] (cf. Ramose 2001). Secondly, it is naïve because it presumes that there is a generally accepted and consensual interpretation of what democracy is.

The article will explore the history of knowledge of the good and evil, the unavoidable original (foundational) sin, in the realm of the 'state', from the time when the church defined the good, to the violent transition to the secular definition of the good, and finally the so-called democratic (consensual) definition of the good.

It will be argued that whoever defines the 'good' has the sovereign right to violence - both Benjamin's law-founding violence and law-maintaining violence (Benjamin 1996), which for Derrida are the same (Derrida 2002).

\section{The church as sovereign authority on what is good}

The article will not focus on the early church, but begin with a short reflection on the Constantine church, in other words the church of Christendom. This early period of church history does not directly bear on the theme of the conference, but functions as an important historical background to the development of the secular and eventually modern democratic state within the West. With the rise of Christendom in the Roman empire the church ruled the empire and had the sovereign authority, and thus the sovereign right to delineate good and evil (different) and thus to determine who the enemy of the state was. In Walter Benjamin's (1996) terminology the church had the sovereign right to coercive violence within the realm of the empire so as to maintain her power within that realm. Benjamin calls this 'law-preserving violence', which he says is the right to define the good and thereby exclude and declare as enemy of the state that which is contrary (different) to this defined good. Kant, reflecting on a totally different context, described the good end [telos] of the state, as to perpetually maintain itself. In order for the state to do this, Kant argues that it must defend itself coercively (1996:131).

It was the exclusive right of the church to determine the good for the whole Holy Roman Empire and thus it was inevitable that at some stage, there would be others (excluded others) who had a different interpretation as to what is good, not necessarily for the whole empire, but certainly for their part of the world. Thus the kings and princes of Europe started questioning the Pope's sovereign right to coercive violence, specifically in their kingdoms. Thus the battle about the sovereign right to coercive violence (law-preserving violence/state-maintaining violence/empire maintaining violence) within a defined territory began. The church was clearly implicated in this violence, because it was the church, as imperial institution, that had the sovereign authority and right to coercive violence (state or law-maintaining violence).
Yet, the church was also involved on the side of the different good that was emerging and that was violently seeking to found a new state and a new law (law-founding violence), thereby questioning the right of the church to coercive violence within the Holy Roman Empire.

When the reformers specifically Martin Luther, in his 1523 treatise on Temporal Authority: to what Extent it Should be Obeyed, split the powers and the realms saying that a Christian is subject to two realms (kingdoms), the spiritual and the secular (temporal), and that the church has coercive power only in the spiritual and that the coercive (law-maintaining) power in the temporal should be the sole province of the secular authorities, they re-defined coercive power, in other words law-maintaining power, as secular (Cavanaugh 1995:339). One can speculate as to what exactly the material conditions were that motivated Luther to develop this treatise, but this treatise became the necessary narrative or mythos [myth] of a universal good that justified the lawfounding violence of the new secular state, where (secular or temporal) state authorities had the sole right to coercive violence (law-maintaining violence). One could easily come to the conclusion that this was a protestant phenomenon, but there were Catholic princes and kingdoms such as the Catholic princes of Germany, the Habsburg of Spain and the Valois of France, who all sought to wrest more coercive power within their territories from the Pope by twisting his arm to grant them these concessions (Cavanaugh 1995:400). The so-called religious wars of Europe were a battle for sovereignty. The battle was about who had the absolute authority over coercive violence (law-preserving violence) and not a confessional battle, as history books now claim. The confessional differences where certainly used, but they were not the main motivation or justification of this violence. This state founding violence (law-making violence) was justified by the new good that the reformers proclaimed, namely the division between secular or temporal and spiritual authority. The principal promoters of this so called religious violence in France and Germany were not the pastors together with the peasants, but kings and nobles: those who had a stake in the outcome of this founding violence in the creation of a centralised hegemonic 'secular' state (cf. Cavanaugh 1995:403).

\section{The birth of the modern term 'religion' and the secular state's monopoly on the definitions of the good}

The so-called religious wars erupted in Europe, giving the impression that these wars were about confessional truths and thus a war about the correct interpretation of the Eucharist (as one example). William Cavanaugh (1995) argues, as already mentioned, that this war was about the division between secular and spiritual authority. One can argue that the secular state developed (law-founding violence) and was justified by this new good of separating spiritual from secular authority. Cavanaugh argues that it 
was with the development of the modern interpretation of 'religion' that the secular state was justified. The creation of 'religion' as a set of beliefs which is defined as personal conviction and which can exist separately from one's public loyalty to the state (Cavanaugh 1995:403), was a necessary step for the shift of power from church to state.

The good, one could say the universal or mythical good that justified the law-founding violence of the secular states of Europe, was the understanding that religion was a private matter that had nothing to do with the public realm.

The creation of religion as a private matter was a necessary step in the law-founding violence of the secular states of Europe. Before this time, the word religio was seldom used and when it was used it was used to refer to monastic life (Cavanaugh 1995:403). It referred to a practice, a way of life that was shaped and formed by faith. It is only during this time, the time of the founding of secular states that it started to refer to a set of truth propositions concerning moral life and no longer referred to a virtuous practice. Once the term had been transformed or translated into this new meaning it also started to become practical to speak of religions in plural as there were different sets of propositions, or propositional truths that people held dear individually and privately. One can, for example, have different propositional statements about the truth of the Eucharist. This step was necessary to define Christianity as a religion. Religion was now seen as a set of demonstrable moral truths rather than as a series of theological claims and practices that took on a particular form called the church (Cavanaugh 1995:404). It was an important step to discover this good in order to justify the creation of a new law that outlawed religious views from the public square. Religion was thus outlawed as it was placed outside the law of the public realm. It was different from secular reason which alone had authority over the public square.

This division between secular and religious was the new discovered good that justified not only the law-making violence (secular state founding violence), but also projected the image of the secular state as the good peacemaker who came to save Europe from warring religious factions. Spiritual authorities could no longer define the common good of the state. In this time of transition, the secular state took up the noble calling of defining the common good.

The secular state was founded (law-making violence) on the myth that religion is the evil that causes conflict and the good that will save us from this evil is the religiously neutral state. There were many who co-authored this myth right into our present time. Theorists like John Rawls (1985:225), Judith Shklar (1984:5) and Jeffrey Stout (1981:235-242) defend the rise of the modern secular state and liberalism as the peacemaker in a time of religious conflict. As Judith Shklar argues:

liberalism ... was born out of the cruelties of the religious civil wars, which forever rendered the claims of Christian charity a rebuke to all religious institutions and parties. If the faith was to survive at all, it would do so privately. The alternative then set, and still before us, is not one between classical virtue and liberal self-indulgence, but between cruel military and moral repression and violence, and a self-restraining tolerance that fences in the powerful to protec the freedom and safety of every citizen ...

(Shklar 1984:5)

This was the powerful myth that helped replace the universal good of the Church's empire with a new universal good of liberalism and tolerance. The idea of this liberal and tolerant state that saved the world from religious violence was that the state is neutral, as the 16th and 17th century French and English humanists offered a definition of the good of the secular state as 'a form of public power separate from both ruler and ruled, and constituting the supreme political authority within a certain defined territory' (Skinner 1978:353). The idea was that a small administrative state would ensure freedom and tolerance within the defined territory. The reality is that more than a third of the workforce labours directly or indirectly under the state and this alone influences the supposedly free debate in the public square. Myths are created around a certain definition or interpretation of the good that are used to justify political actions, laws etc. A founding myth is necessary to declare the founding and preserving violence of the law (state founding and state preserving) just, yet as in all symbolisations and creations of myths, there is a gap between that and the reality and it is towards that gap that the paper now turns.

\section{Deconstructing the good of the secular democracy The so-called small neutral state}

As already mentioned the ideal of the secular state is for it to be a small administrative unit to ensure freedom, neutrality and tolerance within the territory of the state, but in reality one has a large state apparatus. If such a large proportion of the 'free citizens' are directly or indirectly dependent on the state it affects the so-called neutrality of the state. How neutral can a public square be under such circumstances? Besides the large proportion of the population that is employed by the state, what counts as news and information that is offered to the public square is increasingly determined by spin doctors and media handlers, who are part of the state's apparatus. So the information that is meant to inform the free and tolerant debate in the public square is produced by the state itself. The media itself looks for its sources amongst government spokespersons and various 'experts' closely linked to the government apparatus (Cavanaugh 1995:412).

This is not only an issue of big government, as numerous political scientists are arguing that the state, in late capitalism and civil society, is fused into different moments of a single complex (Cavanaugh 1995:412). It has been argued (Meylahn 2010:320-332) that the nation state (within global capitalism) is disappearing and in place of the nation state is a new coercive force justified by a new universal and mythic good, namely global capitalism and the free market. The nation state lost its authority over coercive violence and the market 
(the new good) started to regulate itself. The 'good' shifted from the state as the absolute authority on coercive violence to the market that would determine and regulate everything. The market became the new authority and sole administrator of coercive violence (as both law-making and law-preserving violence) and the new evil was called 'state intervention into the laws of the market' (cf. Meylahn 2010:327). There was a new imperial universal good that dictated to the world the global market (cf. Martin \& Schumann 1998:9). Political, social, cultural spheres have merged to such an extent that culture obeys the logic of the market and the political apparatuses, in turn create spaces for capital to operate. Thus the permissible public discourse is determined by this logic of capital. The logic of capital is presented not as a construct, but as something natural and inevitable (Surin 1990:45).

An interesting development in the history of shifting definitions of good is that this last shift is not very clear. The reason for this is that the market is not recognised as an authoritative law-making and law-preserving institution which is still believed to be in the hands of the secular state. Yet it is not, and this dichotomy can only be justified if this new good is seen as beyond the question of good and evil as something natural and unquestionable. In other words, an absolute good or totalitarian religion, which is the ultimate use of violence.

Žižek (2008a) describes this dictatorship of the 'global capital universal unquestionable good' in his article, Democracy versus the people, where the people of Haiti were forced to accept an interpretation of democracy that coincided with the interest of global capital and the economic elite of Haiti. Ramose (2001) argues that in South Africa there is a similar situation because democracy is to the detriment of the people of South Africa as the constitution protects the rights of a certain economic elite. In other words, the good that the secular state strives for is now placed under coercive violence (state/law forming and state/law preserving violence) justified by the good of global capitalism, namely: the value of the market, scientific progress, the importance of choice (consumption), and these values do not tolerate any rivals (Beiner 1992:20-28). In a sense, one can argue that there is a new universal totalitarian religion that determines the good.

\section{The so-called nonreligious state or religiously neutral state}

Even though a shift has taken place from the state to the market regarding who or what has absolute authority over coercive violence, one is forced to reflect on violence (as well as other concepts) in the space created by the state, as the market is not viewed as a questionable entity, but as a given. Thus public debate and public theology take place within the laws of the nation state and not within the virtual realm of the global market. That is why lately, especially after the economic recession that has taken place in many of the front runners of global capitalism, there is a call for more power to be given to global institutions. This would mean that the coercive power of the market can be institutionalised and once institutionalised (state or institution-making violence) it could be challenged, as the excluded other (different) can start the violence of deconstruction ${ }^{1}$. As long as it is uninstitutionalised, in other words has not translated its coercive law-making violence into concrete state-making violence, it remains untouchable and elusive.

How religiously neutral is the secular state within the global village? In a previous section it was argued that the modern division between secular-public and religiousprivate was a mythological construction that justifies the law-making (state-making) violence. It was part of the new definition of the good - a religiously neutral state. How implementable is such a good? It could be possible to have a confessionally neutral constitution, where the state's laws do not specifically side with a particular religious group or confessional denomination. The question remains 'can a state be religiously neutral'. The term 'religion' came into common use during the period of the rise of the secular state and was used to describe personal moral truth propositions, but the term has continued to undergo transitions. McBrien defines religion as follows:

... the whole complexus of attitudes, convictions, emotions, gestures, rituals, symbols, beliefs, and institutions by which persons come to terms with, and express, their personal and/ or communal relationship with the ultimate Reality (God and everything that pertains to God)

(McBrien 1987:11)

If one takes this definition of religion seriously, is it possible that the public square is ever truly neutral with regards to religion? Does not the human relationship with ultimate Reality ${ }^{2}$, be it God or the market, influence everything?

In seeking a response to this question this article will follow three steps. Firstly, to argue that the common good, or common sense ${ }^{3}$ is embedded in religion; secondly, that the good that the so-called secular modern state in the global village strives for, is coerced within global capitalism which can be interpreted as religion (an universal imperial religion); and thirdly, that the so-called rise of fundamentalism is a symptom of this universal imperial religion and not its opposite or an alternative.

Richard John Neuhaus (1984) argues that religion is part of politics, because politics is a function of culture and at the heart of culture is religion. Politics and the state, as I have argued is about coercive violence (law-preserving violence) and laws in this context need to be seen as a network of binding obligations, the religare, and these laws can only derive their legitimacy or justification from the fact that they express 'what people believe to be their collective destiny (common good or common sense) or ultimate meaning' (Neuhaus 1984:250-251,256). He argues that if one wants to prevent politics from just being a power struggle, the values of the people need to be taken into consideration and these

1.Derrida (2005) refers to the violence of deconstruction as 'auto-deconstruction', which is an inherent violence.

2.This is in reference to Jacques Lacan's way of referring to 'the constructed Real' (1977).

3.The 'common good' and 'common sense' are seen as related and embedded within religion. The 'common good' is based on 'common sense. 
values are deeply entrenched in religion. This idea, that the cultural values, the common good or common sense, is basically religious is based on the thoughts of Clifford Geertz who argued that religion is the 'ground or depth-level of culture' (Neuhaus 1984:132).

Is this new good that the secular modern state strives for under the coercive violence (unwritten law-making violence) of the global markets, which sets the parameters for public debate and consensus formation, an imperial or totalitarian religion? Philip Goodchild (2002) certainly believes that capitalism functions sociologically as a religion. This idea was already mentioned by Walter Benjamin in 1921 when he argues that capitalism is a religion (Amery 2002:29) and that the so-called cultural values that an individual might value are only accessible through the value of money (Goodchild 2008:10). Money only has value when it is in motion, in other words money that is invested. Thus value is determined by speculative projections. Capitalism, Goodchild argues, is essentially a speculative value as it functions on the basis of a promise of future wealth:

It is credit: an offer of value in advance. It cannot be understood according to an eternal ontology as accumulated wealth; it cannot be understood according to a temporal ontology as 'value in motion'. Both appeal to the promise of a future return. Being transcendent of material and social reality, yet the pivot around which material and social reality is continually reconstructed, financial value is essentially religious.

(Goodchild 2008:11)

It is in this sense that one can argue that the secular postmodern state in the global financial village is not without religion understood as religare - that which binds and orders social reality. Thus the so-called return of religion is in a sense ironic as religion has always been there, both in the sense of the common sense as embedded in religious values as well as the ultimate good of the market functioning as a religion. The question that comes to mind is 'How do these different religious phenomena relate to each other'? How does the universal religion of the market relate to the specific religions that influence the common good or sense? The secular state argues that it is tolerant of different religions and that individuals are free to choose their private religion as long as this private religion does not disturb the functioning and the good of the universal religion of the market.

From the aforementioned it is clear that the only religion(s) that is tolerated is a religion that allows its core values and beliefs to be translated into the core values and beliefs of the dominant religion of the market.

This imperial universal religion wears the mask of religious tolerance as there is a great emphasis on freedom of speech and freedom of choice from the multicultural and multimoral/ethical/spiritual/religious market of possibilities, but this freedom is just the rhetoric of pluralism and tolerance to mask the uniformity and homogenising tendencies of the universal religion of capital. Žižek (1997) argues that this tolerance and pluralism is a symptom of the universal religion of capital, in other words it is not an alternative, but a product and necessarily part of its logic. For example, the 'subject of free choice' in the so-called tolerant multicultural/ multimoral/multireligious sense, can only emerge as such as the result of an extremely violent process of being uprooted from one's particular life-world into the life-world of a consumer, who consumes religious and cultural goods (Žižek 2005:118). The individual is disembodied from his or her particular religious or cultural life-world and forced to embrace the individualised concept of self as a consumer of religious and cultural goods. This has become clear over the last few months in Europe in the debate surrounding the wearing of the burka by Muslim women. A woman is allowed to wear the burka if she wears it out of 'free choice', as an expression of her individual eccentric self, in other words she is allowed to wear it if she wears it as an individual consumer of cultural goods. If on the other hand she wears it out of respect for her religion she is labelled a fundamentalist. This 'freedom of choice' is a pseudo choice because you can only choose it if you first accept yourself as an individual consumer. Thus the so-called nonviolent tolerance of pluralism comes at an extremely high price that coerces individuals to interpret and understand themselves as consumers of cultural and religious goods. The market coerces individuals to interpret themselves as consumers. Individuals cannot interpret themselves according to the values of ubuntu, or the Muslim faith or Christianity as they then will be labelled as a fundamentalist or at worst a terrorist. What individuals are allowed to do is to pick and choose from ubuntu, Christianity and any other faith, that which they as consumers of religious goods fancies. Ultimately, the individual must remain a consumer and not become a Christian or Muslim, whose faith determines their whole existence.

It is in the light of this argument that the rise of fundamentalism needs to be interpreted. It is not a return to premodernity or an antimovement to global capitalism, but a symptom. It is a symptom of the universal capital's law-making violence and law-preserving violence. Žižek argues that ethnic and religious:

... fundamentalism and xenophobia are not only not 'regressive', but, on the contrary, offer the supreme proof of the final emancipation of the economic logic of market from the attachment to the ethnic 'Thing'. ${ }^{4}$

(Žižek 1997:45)

In another article Žižek argues that the Milosevic regime was not the opposite of the New World Order as some like to interpret it, 'but rather its symptom, the place at which the hidden truth of the New World Order emerges' (Žižek 1999:79). He has a similar interpretation of the 9/11 New York terror attack (Žižek 2002).

In a sense there is a return of religion as and of religious warfare, but not in the sense of the Christian West against the Muslim other as some would like us to believe, but

4.This 'Thing' is in reference to Lacan (1977) and Marx, and the fetish with regards to objects of desire. 
warfare (violence) internal to the universal religion of capital. If theology wants to be public it will need to address that religion.

\section{Understanding the history of the violence of the knowledge of good and evil}

I have followed the history of the knowledge of good and evil in the rise and fall of the secular modern Western nation state. I believe this plays an important part in the violence experienced in democratic South Africa. The South African democratic constitution, hailed by many as the best in the West, is exactly that: a constitution constructed on the best democratic values of Western history at the exclusion of some valuable insights from other traditions. This history will be investigated in the next section by looking at the dynamics of power within this knowledge of good and evil from different perspectives.

\section{The dynamics of power}

From the argument thus far, it is clear that the search for the good (peace) of the republic has very little to do with ethics, and has everything to do with power and who has the sovereign right to coercive violence within the state. It also now, in late capitalism (Global Capitalism), defines who has the right to coercive violence in the global village - to wage war on terrorism, to declare states as rogue states and to prescribe how nation states are to interpret democracy. It reminds one of the old saying that might is right or as La Fontaine says: 'The strong are always best at proving they're

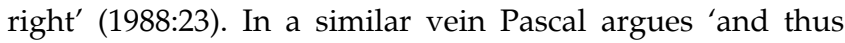
being unable to make what is just strong, we have made what is strong just' (1910:104).

Yet the search for the good continues and it is now believed to be found in dialogue and consensus. This dialogue has to be inclusive and thus religion is invited back into the public debate. Is this how the return of religion is to be understood in public debate?

There are a number of flaws in this 'good' of consensus formation in politics and public debate. As Alain Badiou says, for any philosopher, anything that is consensual becomes suspicious (2000:30). It becomes suspicious for two reasons, firstly because I believe that this consensus formation is part of the mask or the symptom of the universal religion of capital. The universal religion of capital says you can talk about anything as the public space is neutral and tolerant, and therefore you can choose from the plurality of topics without any moral interventions from the side of the state. You can talk about human cloning, genetic manipulation and you can bring in differing voices, as long as you talk about these things within the basic values of: free market, science and technology and the importance and freedom of choice. As long as these values of global capitalism remain unchallenged you can talk about anything. This is the 'good' that justifies the coercive violence of global capitalism and that sets the limits or the parameters of consensus formation. The second reason why I am suspicious about consensus formation is not only the coercive violence of capital external to the consensual space, but the imbalance of power internal to it.

I will reflect on these two reasons of my suspicion by having a closer look at consensus formation, as this is often the path that is chosen by public theologians and conflict managers. One of the greatest proponents of consensus formation is Jürgen Habermas. Habermas was for years a great supporter of a religiously neutral state and vehemently argued against the return of religion, but after 9/11 he opened the door for the return of religion to public debate. Yet he maintains that for religion to be allowed to partake in consensus formation it needs to recognise and accept 'the voluntary character of religious association' (Habermas 2003:6). I completely agree with Habermas as I believe that there is no way in which one can support religious fundamentalism.

Habermas argues that a common language (consensus) should be found so that consensus formation can become possible (2002:65). The old oppositions, religious language and rational language of science and technology, which in the past engaged in dialogue, need to find a mediator because this dialogue has always favoured the rational language. This mediator is common sense. Common sense is where religion can play an active role. Habermas does not argue in favour of secularisation that seeks to destroy religion, but secularisation that seeks to translate religious values into the rational language of common sense (2002:73).

Matustik (2004:8) describes this Enlightenment dream of Habermas as the linguistified God. Into the empty space vacated by the transcendent divinity, Habermas projects the ideal communication community. What does this mean for public theology? It means that public theology cannot follow the route of for example the moral majority in the USA who tried to enter the public debate with arguments derived from sources of revelation or disposition that are essentially private and relative to the source, for example the Bible. Michael and Kenneth Himes (1993:15-19) try and circumvent this relativism of specific sources of authority, by arguing that certain theological symbols are classics and therefore bear disclossive possibilities for all people in the public sphere, even those who might not share the specific religious tradition. Thus religious values and symbols need to be translated into common culturally accepted values. This is a coercive act of violence that places pressure on public theology to speak only in a language that is permissible within the so-called neutral state and if it subjects its language and content to the coercive discipline of capital.

The second reason for my suspicion mentioned earlier is the inequality within the public square. In reality there is no equal striving for consensus, but there are all sorts of power games involved. As was mentioned earlier there are certain values that may not be contravened and thus the dominant values of captial dictate the paradigm within which this 
consensual debate may take place. The real issues may not be addressed in this debate, but only those issues that are 'appropriate' for public debate within the ambit of global capitalism. This is the one side of the problem. The other is that any consensual agreement can only take place through a normative exclusion of some other.

Shiffman (2002:182) says, democracy without institutionalised disagreement is simply not democracy and therefore Derrida (2005) argues that democracy is always something still to come. This space of communicative practice and consensus seeking is not neutral and equal, and thus needs to be interpreted within the:

... historical and contingent character of discourses that construe our identities and constitute the language of our politics; language that is constantly modified, that is entangled with power and needs to be apprehended in terms of hegemonic relations.

(Mouffe 2002:98-99)

Democracy needs to be interpreted in terms of the hegemonic relations of the universal religion of capital. In an unequal society like South Africa it is clear that although there might be plenty of good will to truly seek consensus on certain issues, because of the great inequality in society any consensus on the basis of an ideal speech situation ${ }^{5}$ is impossible.

Foucault suggests that one must use this 'agonistic' ${ }^{\prime}$ space and not see it as an obstacle (1994:238). He describes 'agonism' as 'a gymnastic relation characterised by a play of interpretations and anticipations' (Foucault 1994:238). The art of this gymnastics is not to try and dominate the other, but to anticipate and exploit its interventions, and thus to make one's own intervention of (counter)strategies (Foucault 1994:238). Foucault would argue that to seek consensus in such a situation would result in a reign of violence (Foucault 1994:236) and would suspend the autonomy of the actors (role-players) who are involved. The aim should not be to resolve conflict as this would be a simplistic and dangerous illusion (Mouffe 1996). Resolving conflict can only happen through the construction of a 'we' and a 'they'. The aim needs to be to move beyond good and evil. As long as there is a division between good and evil, irrespective of how this good is found or constructed, even by consensus, the agreement (common good) reached 'will thus be partial, based on acts of social regulation and exclusion' (Hillier 2003:42). Thus there will be consensus, but not all will be included and the excluded will at some stage stand up in revolt against their exclusion. Ramose (2001) speaks of the extremely Eurocentric constitution in South Africa that is also based on consensus (but unequal) thus it excludes the thinking and values of ubuntu. In a sense one could also in South Africa talk about a democracy versus the people as Žižek spoke about in Haiti. Yet a 'good' has been found, probably the best democratic constitution in the world. The problem is that this 'good' is still based on violence and exclusion. Outside the defined (constitutionally defined) good, there is surplus of meaning, that which is different.

5.This is a concept coined in the tradition of Habermans referring to a situation where everybody has an equal opportunity to speak.

6.'Agonistic space' is a term used by Foucault and many other philosophers to describe the 'space' that exists between two opposing views.
The 'surplus meaning' (Dyrberg 1997:196) that cannot be controled, as it is not included in the 'we', will thus eventually challenge this construction based on consensus and conflict resolution. The violence which may result from the knowledge of good and evil, no matter how one arrives at this knowledge, will always perpetuate itself as it remains a violence of and against difference.

Such a dream of a social-political institution as a harmonious totality or a public sphere with complete information and consensus is no more than a fantastic mirage or in Lacanian terms impossible 'Real' of utopian dreams (Hiller 2003:45).

\section{Language analysis}

From the argument made thus far it becomes clear that the route to follow cannot be consensus formation. Consensus happens at the expense of the weaker and in favour of the stronger, and within the paradigms set by the stronger, in this case the global capitalist order. Secondly, consensus always includes its own potential violence as the construction of a 'we' can only happen through the simultaneous construction of a 'they'. The good or common good of consensus is not a way forward, nor is any other way that seeks to reconcile or integrate otherness or difference into a greater whole or greater good, thereby denying or excluding that otherness or difference. It seems that the moment one eats of the fruit of the knowledge of good and evil one enters into the violence of judgement, exclusion and condemnation. What is needed, Žižek (1997:50) argues, is 'to paraphrase Kierkegaard, to accomplish a political suspension of the Ethical', in other words, to go beyond the knowledge of good and evil. Žižek suggests that this 'beyond' can be reached if one identifies with the symptom:

This procedure of identifying with the symptom is the exact and necessary obverse of the standard critical and ideological move of recognizing a particular content behind some abstract universal notion ('the "man" of human rights is effectively the white male owner'), of denouncing the neutral universality as false: in it, one pathetically asserts (and identifies with) the point of inherent exception or exclusion, the 'abject', of the concrete positive order, as the only point of true universality, as the point which belies the existing concrete universality. ...identifying universality with the point of exclusion.

(Žižek 1997:51)

This sounds very similar to Matthew 25 where judgement is no longer on the basis of knowing and practicing the good, but purely on identifying with the excluded, the exception, the abject. Not trying to identify with the universal law of the good, but seeking that which is excluded by that law. The challenge is to identify with that which is outside or beyond the law (marginalised, ostracised by the law), to identify with the surplus meaning, the different. Does one identify with the different and thereby define a new good? No, as Žižek argues the way to go is to maybe read Rancière's notion of singulier universel: 'the assertion of the singular exception as the locus of universality which simultaneously affirms and subverts the universality in question' (Žižek 1997:51). The 
singulier universel exposes the universality in question; it exposes the law of the universal, but not by promoting a new universal or good.

To better understand this 'beyond the law' one needs to return to the violence within language.

Walter Benjamin (1996:245) argued that there is only one place to look for nonviolence and that is in the sphere of relationships amongst private persons. This is the only 'sphere of human agreement that is non-violent to the extent that it is wholly inaccessible to violence: the proper sphere of "understanding", language' (Benjamin 1996:245).

All hope for peace and conflict resolution is placed in the hands of language and the understanding that humanity is a linguistic communicating animal. This is also the mainstream tradition within peace movements and conflict resolution theories: that language and the symbolic order is the one medium of reconciliation and mediation and thus the only possibility for peaceful coexistence. The work of Jürgen Habermas, as has been discussed, is a great defence of the possibilities of communicative practice and ideal speech situations in seeking consensus, but it remains an ideal which is removed from historical political reality. Besides the historical political reality that challenges the 'Real' of ideal speech situations it is language itself which is violent. Derrida argues that in language there is an arche-violence that is tied to the very possibility of language itself (1978:125). Arche-violence, the primordial violence, appears with every articulation (Derrida 1978:148) as in every articulation there is choice, classification and thus also exclusion of that which does not fit, which is different. In other words speech without choice, classification, differentiation would not be speech, because it would say nothing. Žižek says, 'This is why language itself, the very medium of non-violence, of mutual recognition, involves unconditional violence' (Žižek 2008b:2).

Žižek refers back to Heidegger's interpretation of the essence of language not as the core truth of language, but the 'essencing' ability of language and he says:

A fundamental violence exists in this 'essencing' of language: our world is given a partial twist, it loses its balanced innocence, one partial colour gives the tone of the whole.

(Žižek 2008b:3)

Because of this 'essencing' character of language Heidegger spoke of language as the house of being. This metaphor has been taken further, specifically within psychoanalysis where one can speak of language as the torture-house (Žižek $2008 \mathrm{~b}: 3-4)$. This violence (the violence of language) is a given and it cannot be avoided.

What Žižek proposes is that we need to be aware of this violence and to think this violence ${ }^{7}$. In agreement with Hegel, Žižek argues that we need to think language against language and thus he comes back to Benjamin and the two forms of violence (mythic and divine). The violence of language which Derrida and Heidegger refer to is mythic violence [sprach-bildende Gewalt] with the force of mythos [myth] as the primordial narrativisation or symbolisation, or to put it into Badiou's (2000) terms the violent imposition of the transcendental coordinates of a world onto the multiplicity of Being. This sprachbildende Gewalt [mythic violence] can be compared to the law-making violence that is based on a specific understanding of the good, which acts as the necessary mythos, primordial symbolisation, with which to justify the law-making or law-maintaining violence against what is different.

In contrast to this, Žižek picks up a thought from Lacan (1977) who returns to Descartes' Cogito ergo sum [I think, therefore I am], and argues that there is also the violence of thinking (and of poetry) and this can be compared to Benjamin's (1996) divine violence as sprach-zerstörende Gewalt [mythic violence]. In other words, to think [cogito] - not the self-transparency of pure thought, but paradoxically cogito is the subject of the unconscious - the gap or cut in the order of Being in which the real of jouissance breaks in (Žižek 2008b:9).

Thus Žižek (2008b:11) argues, one needs to focus on (think) the destroying twisting of language in order to enable a transsymbolic 'Real' of a 'Truth' to transpire in it. So, there is a language that can be used for peace, but not where Benjamin and Habermas seek it. It is a language of pure mathematics, of poetry. Lacan played with the term mathem [writing] (Žižek 2008b:11).

Derrida would probably call it by another name, but what is in a name? It is about thinking the différance, being open to the différance and thereby seek not an absence of violence, but an economy of violence that does not strive for equilibrium (as it is not static), as différance is both the difference and deferment. This is exactly where the difference lies between Derrida's (1982:3-27) différance and Žižek's minimal difference or pure difference or the gap/cut. When Žižek equats différance with pure difference he denies the important movement and force in thinking of différance (Sands 2008a:531). Žižek (2006a) argues that pure difference is not between the other and the same, but is the difference within the same. This pure difference Žižek interprets into the relationship between God and Son in the incarnation where the limitation or difference has shifted from without God to within God. Thus the idea of a transcendent God is removed and only a materialist interpretation is possible. In his book, The Paralax View, Žižek (2006a) offers a description of God that can be compared to his interpretation of différance:

Perhaps 'God' is the name for this supreme split between the Absolute and the noumenal Thing and the Absolute as the appearance of itself, for the fact that the two are the same, that the difference between the two is purely formal.

(Žižek 2006a:109)

Because of his static view of difference, Žižek can argue that the Christ event has happened and is not something to be expected. He says: 
... while Christianity, far from claiming full realization of the promise, accomplishes something far more uncanny: the Messiah is here, he has arrived, the final Event already took place, and yet the gap (the gap that sustained the messianic promise) remains.

(Žižek 2006b:232-233)

The gap remains, but it is empty of force and movement, because of Žižek`s interpretation of Derrida. I believe that this is the site of the return of Christ-like faith and the role of the church in the public debate of a violent democracy and I will turn to the political theology of Saint Paul in dialogue with Žižek and Derrida.

\section{A theological interpretation beyond good and evil towards a public theology of différance}

The church in the history of its relationship with politics or with regard to its role in the public domain since Christendom has too often been understood to fight the good fight in the name of the good. It has understood its task to take up the good cause - onward Christian soldiers marching as to war. This is also how many Christians understand their Christianity - to fight the good fight, not of faith but of some or other interpretation of the good. This is a generalisation and throughout the history of the church and Christianity there have always been other interpretations of the church's and the Christian's role.

The famous hymn referred to above by Sabine Baring-Gould (1973:208) says 'as to war' and these words can be interpreted in two different ways. It can be interpreted as war, in other words, to enter into the perpetuating violence of the knowledge of good and evil. Yet it can also be interpreted 'as to, but not exactly'. And then comes the next line, which is so often forgotten: 'with the cross of Jesus who has gone before'. Is there a way for public theology, beyond good and evil? Is the church's role within a democratic state to help define, authorise and sanction the good that binds the state? Derrida would argue that there is no 'beyond violence'. At best there is only an economy of violence and to learn to live with the différance. Yet Derrida's word différance refers to both difference and deferment. In the concept 'democracy' there lurks the event of the name's truth, namely the possibility of giving everyone within the state a chance to be heard and taken seriously. The various democracies, and specifically the democracy that is in South Africa, are always a far cry from this call that is harboured in the word 'democracy'. The difference between the call (truth of the event in the name democracy) and 'reality' can be described as being different as democracy is never perfect, but also as deferment as democracy is never finished, but always a responsibility of the citizens to strive towards greater democracy.

The church finds itself in a similar relationship of différance with regards to its role as an instrument of the kingdom of God in the time that remains before the second coming. There is a space of deferment between an act and its judgement and this space is a liminal space of grace:
Life itself consists in the delay between deed and judgment. It is in the time that remains, between and beyond synchronic universals, that one may be saved. It is a time of pure contingency, beyond reason.

(Goodchild 2008:24)

In this liminal space (of the time that remains) the crime or sin is judgement itself, based on the knowledge of good and evil as judgement would no longer be deferred and time itself would become captive to the present, which would be idolatry and the end of history. The Apostle Paul interprets the cross as the suspension of not only the law, but also the mythological foundation of the law, as the law can only lead to death and not life, and judgement is deferred to judgement day. What remains is a time of grace.

This Christ event changes everything for the church, but not in the name of a new good, rather as an invitation into this gracious time that remains. So where does this leave Christians who follow Christ in a violent democracy? It leaves Christians in the liminal space of grace where judgement is deferred, and no longer on the basis of good works, but on the secrets of the heart.

Is the heart secretly worshiping the law of death ${ }^{8}$ or is the heart dependent on Christ as the suspension of the law of death? How does this theology translate into public action if action is unavoidably violent as it is based on judgement? One cannot avoid judgement in action, but one can be aware that the 'good' which determined the judgement stands under the cross and is no absolute universal, and therefore is in need of constant revision. The church's public role can only be in weakness and faith. Such dependence on Christ in action can best be described as prayer directed in expectation toward the Other and thus beyond good and evil. Public theology as prayer - the address and expectation of the Other. A nonviolent (not law creating nor law preserving) deconstruction (law destroying violence) from the liminal space of deferred judgement, should be the role for the church in a violent democratic South Africa.

\section{References}

Amery, C., 2002, 'Die Reichsreligion des Totalen Marktes' [The Imperial Religion of the Capitalist Market], Publik-Forum 8, 28-30.

Badiou, A., 2000, 'The Concept of Democracy', Lacaninan Ink 16, 28-43.

Baring-Gould, S., 1973, Onward, Christian Soldiers, Lutheran Publishing House, Adelaide.

Beiner, R., 1992, What's the Matter with Liberalism?, University of California Press, Berkeley.

Benjamin, W., 1996, 'Critique of Violence', in M. Bullock \& M.W. Jennings (eds.), Walter Benjamin. Selected Writings Vol 1 1913-1926, pp. 236-252, Harvard University Press, Cambridge.

Cavanaugh, W.T., 1995, "A fire strong enough to consume the house:" the wars of religion and the rise of the state', Modern Theology 11(4), 397-420. doi:10.1111/j.1468-0025.1995.tb00073.x

Derrida, J., 1978, Writing and Difference, University of Chicago Press, Chicago.

Derrida, J., 1982, Différance in Margins of Philosoph, transl. A. Bass, University of Chicago Press, Chicago.

Derrida, J., 2002, 'Force of Law: The Mystical Foundation of Authority', in G. Anidjar (ed.), Acts of Religion, pp. 228-308, Routledge, London.

Derrida, J., 2005, Rogues: Two Essays on Reason, transl. P.-A. Brault \& M. Naas, Stanford University Press, Stanford.

Dyrberg, T., 1997, The Circular Structure of Power, Verso, London.

8.'The law of death' is a Pauline concept. 
Foucault, M., 1994, 'Le Sujet et le Pouvoir '[Subject and Power], in P. Rainbow (ed.), Dits et Ecrits Vol. 3, pp 222-243, Gallimard, Paris.

Goodchild, P., 2002, Capitalism and Religion: The Price of Piety, Routledge, London. doi:10.4324/9780203398418

Goodchild, P., 2008, 'The Exceptional Political Theology of Saint Paul', viewed 08 May 2010 from, http://theologyphilosophycentre.co.uk/papers/Goodchild

Habermas, J., 2002, 'Glauben und Wissen' [Faith and Knowledge], Dialog 1(1), 63-74

Habermas, J., 2003, 'Intolerance and Discrimination', International Journal of Constitutional Law 1(1), 2-12. doi:10.1093/icon/1.1.2

Hillier, J., 2003, 'Agon'izing over consensus: why Habermas' Ideals cannot be "Real"', Planning Theory 2(1), 37-58. doi:10.1177/1473095203002001005

Himes, M. \& Himes, K., 1993, Fullness of Faith: The Public Significance of Theology Paulist Press, New York.

Kant, I., 1996, Metaphysics of Morals, M. Gregor, (ed), Cambrige University Press, Cambridge.

Lacan, J., 1977, Ecrits, transl. A. Sheridan, W.W. Norton, New York.

La Fontaine, J., 1988, The Complete Fables of Jean de la Fontaine, transl. N.B. Spector, Northwestern University Press, Evanston, IL.

Martin, H.-P. \& Schumann, H., 1998, The Global Trap: Globalization and the assault on prosperity and democracy, HSRC, Pretoria.

Matustik, M.B., 2004, 'Between Hope and Terror: Habermas and Derrida Plead for the Im/Possible', Epoché 9(1), 1-13.

McBrien, R., 1987, Caesar's Coin, MacMillan Publishing Company, New York.

Meylahn, J.-A., 2010, The Church in the Postmodern Global Vilalge: Towards Pastoral Redemptive Communities (Vol. One), Lap Lambert Academic Publishing, Saarbrücken.

Mouffe, C., 1996, 'Deconstruction. Pragmatism and the Politics of Democracy', in C. Mouffe (ed.), Deconstruction and Pragmatism, pp. 1-12, Routledge, London.

Mouffe, C., 2002, 'Which Kind of Space for Democratic Habitus?', in J. Hillier \& E. Rooskby (eds.), Habitus: A Sense of Place, pp. 93-100, Ashgate, Aldershot.

Neuhaus, R.J., 1984, The Naked Public Square, William B. Eerdmans, Grand Rapids, Michigan.
Pascal, B., 1910, Thoughts, transl. W.F. Trotter, Collier, New York.

Ramose, M.B., 2001, 'An African perspective on justice and race', Polylog:Forum for Intercultural Philosophy 3 , viewed 27 June 2010, from http://them.polylog.org/3/ frm-en.htm

Rawls, J., 1985, 'Justice as Fairness Piolitical not Metaphysical', Philosophy \& Public Affair 14:3, 223-251.

Sands, D., 2008, 'Thinking through différance: Derrida, Žižek and religious engagement', Textual Practice 22(3), 529-546. doi:10.1080/09502360802263774

Shiffman, G., 2002, 'Construing Disagreement: Consensus and Invective in "Constitutional" Debate', Political Theory 30(2), 175-203 doi:10.1177/0090591702030002001

Shklar, J., 1984, Ordinary Vices, Harvard University Press, Cambridge, MA.

Skinner, Q., 1978, The Foundations of Modern Political Thought (Vol. 2), Cambridge University Press, Cambridge.

Stout, J., 1981, The Flight from Authority Religion, Morality, and the Quest for Autonomy, University of Notre Dame Press, Notre Dame.

Surin, K., 1990, 'Marxism(s) and the "Withering Away of the State"', Social Text (27), $42-46$.

Žižek, S., 2008a, 'Democracy versus the People', New Statesman, viewed 14 August, from, http://www.newstatesman.com/books/2008/08/haiti-aristide-lavalas

Žižek, S., 2008b, 'Language, violence and non-violence', International Journal of Zizek Studies 2(3), 1-12.

Žižek, S., 2006a, The Paralax View, MIT Press, Cambridge.

Žižek, S., 2006b, 'A Plea for a Return to Différance', Critical Inquiry Winter (32), 226249.

Žižek, S., 2005, 'Against Human Rights', New Left Review 34, 115-131.

Žižek, S., 2002, 'Welcome to the Desert of the Real', South Atlantic Quarterly 101(2), 385-389. doi:10.1215/00382876-101-2-385

Žižek, S., 1999, 'Against the Double Blackmail', New Left Review I (225), pp. 76-82.

Žižek, S., 1997, 'Multiculturalism, Or, the Cultural Logic of Multinational Capitalism', New Left Review I (225), 34-51. 